\title{
POLITTIKK
}

Årgang 78, Nummer 1, side 43-53, 2020, ISSN 1891-1757, www.tidsskriftet-ip.no, Publisert februar 2020

\author{
FOKUS: KinESISKE INVESTERINGER I NORDEN
}

\section{Danmarks politik i forhold til kinesiske investeringer: Pragmatisk balancegang mellem voksende trusselsperspektiver}

\author{
Yang Jiang \\ Dansk Institut for Internationale Studier (DIIS)
}

\begin{abstract}
Sammendrag
Igennem de sidste to år (2018-2019) er den førte danske politik i forhold til Kina blevet mere ambivalent. Særligt når det gælder kinesiske investeringer, er Danmark blevet mere forsigtig. Denne artikel undersøger hvilke faktorer, der har haft betydning for Danmarks skiftende politik i forhold til kinesiske investeringer, gennem to større case-studier: Kinesiske investeringer i Grønland og Huawei i Danmark. Kort fortalt udpeges her tre faktorer, der er afgørende for Danmarks politik i forhold til kinesiske investeringer: for det første landets langvarige økonomiske ideologi som en lille, åben økonomi, svarende til øvrige nordiske lande og som medlem af EU, med et pragmatisk behov for udenlandske markeder; for det andet en stærk, national tro på demokrati og statens forsvarsalliance med USA, herunder dets dedikerede medlemskab af NATO; og for det tredje opkomsten af fremmedfjendske og nationalistiske politiske partier, der udfordrer den tidligere mere afbalancerede og pragmatiske tilgang kendetegnende for større partier samt går ind for et mere anti-kinesisk standpunkt.
\end{abstract}

Nøgleord: dansk politik · kinesiske investeringer $\cdot$ Grønland $\cdot$ Huawei

\section{Indledning}

Ved EU-topmødet i juni 2017 var Danmark sammen med andre nordiske lande, de baltiske stater og Holland imod Frankrigs, Tysklands og Italiens forslag om, at EU

\footnotetext{
^Kontaktinformasjon:Yang Jiang, e-post: yaji@diis.dk

(C)2020 Yang Jiang. This is an Open Access article distributed under the terms of the Creative Commons Attribution 4.0 International License (http://creativecommons.org/licenses/by/4.0/), allowing third parties to copy and redistribute the material in any medium or format and to remix, transform, and build upon the material for any purpose, even commercially, provided the original work is properly cited and states its license.

Citation: Yang fiang (2020). Danmarks politik i forhold til kinesiske investeringer: Pragmatisk balancegang mellem voksende trusselsperspektiver. Internasjonal Politikk, 78(1):43-53. http://dx.doi.org/10.23865/intpol.v78.2058
} 


\section{Yang Fiang}

skulle styrke kontrollen af udenlandske investeringer. Danmark handlede ud fra sin tro på et åbent marked og forfulgte dermed sine pragmatiske interesser som en lille, åben økonomi. Da to pandaer landede i København d. 4. april 2019 i et SAS-fragtfly, der var specialmalet til lejligheden, var det meningen, at de kinesisk-danske relationer skulle træde ind i en ny fase. Men igennem de sidste to år (2018-2019) er den førte danske politik i forhold til Kina blevet mere ambivalent. Særligt når det gælder kinesiske investeringer, er Danmark blevet mere forsigtig. Som i andre europæiske lande har bekymringer i forhold til den nationale sikkerhed ført til, at Danmark nu styrker de screeningsmekanismer, der går forud for investeringer fra udlandet. I år (2019) arbejder Danmark på en lov, der giver regeringen mulighed for at gribe ind ved udenlandske investeringer i kritisk infrastruktur (Breinstrup, 2019).

Denne artikel undersøger hvilke faktorer, der har haft betydning for Danmarks skiftende politik i forhold til kinesiske investeringer, gennem to større casestudier: Kinesiske investeringer i Grønland og Huawei i Danmark. Kort fortalt udpeges her tre afgørende faktorer: for det første landets økonomiske ideologi som en lille, åben økonomi med et pragmatisk behov for udenlandske markeder; for det andet en stærk, national tro på demokrati og statens forsvarsalliance med USA; og for det tredje opkomsten af fremmedfjendske og nationalistiske politiske partier.

Første del af artiklen giver en generel baggrundsviden i forhold til det politiske og økonomiske miljø i Danmark, derefter følger to afsnit med casestudier af hhv. Grønland og Huawei inden den afsluttende opsummering af de faktorer, der har størst betydning for Danmarks politik i forhold til kinesiske investeringer.

\section{Politisk og økonomisk miljø for kinesiske investeringer i Danmark}

Det danske miljø for kinesiske investeringer inkluderer to aspekter: Danmarks generelle åbenhed over for udenlandsk investering samt landets specifikke relationer til Kina. Som en lille, åben økonomi, der er stærkt afhængig af international handel, har Danmark været meget tilgængelig for udenlandske investeringer. Der er ejerskabsrestriktioner på sektorerne for fly- og forsvarsmateriel, kulbrinteefterforskning, maritim og landfast ejendom samt restriktioner i forhold til at etablere firmaer, der udbyder offentlige, professionelle tjenester ( $\mathrm{fx}$ inden for jura, regnskab, revision og sundhed). Men screening af udenlandske investeringer har kun været foretaget $\mathrm{i}$ tilfælde, hvor der er tale om mulighed for monopol (The Law Reviews, 2018). Overordnet set er forretningsverdenen så åben og veludviklet, at Verdensbanken i 2018 placerede Danmark som nummer tre (ud af 190 lande) på ranglisten over, hvor let det er at drive virksomhed i landet (Ease of Doing Business Index). De love og regler, der blev implementeret af den nu afgående centrum-højre regering (20152019), inklusive Vækstplan DK for 2014-2020, var ikke-diskriminerende og rettet mod en større åbenhed (Santander Trade Portal, 2019).

Kigger man lidt tilbage i tiden, hvad angår kinesisk-danske relationer, var Danmark i 1950 et af de første lande, der anerkendte den nyligt grundlagte 
Folkerepublik Kina; Danmark er den eneste nordiske stat, der har indgået en omfattende strategisk partnerskabsaftale med Kina, etableret i 2008 og opskaleret med et bredt samarbejdsprogram for de følgende tre år i 2017 (Ministry of Foreign Affairs of Denmark, 2017); ligeledes meldte Danmark i 2015 sig som stiftende medlem af den kinesisk grundlagte Asian Infrastructure Investment Bank (AIIB) på trods af amerikansk pres for det modsatte.

Det eneste større tilbageslag for det dansk-kinesiske forhold var, da Dalai Lama i 2009 besøgte den danske statsminister, Lars Løkke Rasmussen, hvorefter Kina nedfrøs de bilaterale relationer, hvilket fik København til prompte at bekræfte sin støtte til et-Kina-politikken. I de senere år har de to landes gode relation stået som en model for kinesisk-europæisk samarbejde og et eksempel på, hvordan to lande med hvert sit politiske system, hver sin økonomi og kultur kan arbejde og handle sammen.

Danmark underskrev en gensidig investeringsaftale med Kina i 1985 og har vedholdende argumenteret for at give Kina status som markedsøkonomi i EU, fordi man mener, at åbenhed er det mest gavnlige både for Danmark og for EU. Da EU og visse europæiske lande blev mere skeptiske overfor kinesiske investeringer, smittede dette kun i mindre grad af på Danmark, som i 2017 også var imod et lovforslag om en bindende EU-lov om screening af udenlandske investeringer.

Erhvervslivets organisationer, som fx Dansk Industri og Dansk Erhverv, ser Kina som et vigtigt eksportmarked og investeringskilde. Men selvom det samlede antal kinesiske investeringer er steget hastigt gennem de sidste ti år, har værdien af de fleste enkeltinvesteringer ikke været høj - fra 100-500 mio. \$ (Baker \& Mckenzie, 2016, s. 13). Den samlede værdi af kinesiske direkte investeringer i Danmark i perioden 2000-2018 ligger på 1,2 mia. €, og Danmark er således langt bagude $i$ forhold til sine nordiske naboer, Sverige $(6,1$ mia. $€$ ) og Finland (7,3 mia. €) (Haneman, Huotari \& Kratz, 2019). Det er især Danmarks kompetencer inden for vedvarende energi (biomasse og vind), sundheds- og velfærdsløsninger, akustik, robotteknologi og IT, der er attraktive for kinesiske investorer. I 2018 erhvervede den kinesiske virksomhed, Geely, aktiemajoriteten i den danske investeringsbank, Saxo Banks finansierings- og reguleringsteknologier. Endvidere er det stærke R\&D miljø, paratheden til at benytte den nyeste teknologi og det positive investeringsklima med til at gøre Danmark til et attraktivt land for kinesiske investeringer. Sidst men ikke mindst er Grønland fortsat interessant for den kinesiske regering og kinesiske selskaber, pga. landets naturressourcer og den arktiske sejlrute. Som denne artikel senere vil komme ind på, har kinesiske minefirmaer gjort fremskridt i Grønland, men deres interesser $\mathrm{i}$ infrastruktur har skabt ophedede politiske debatter (Jiang, 2017).

Den danske regering har tidligere forsøgt at tegne et positivt billede af kinesiske investeringer i landet. En solskinshistorie er, at Vestas i 2012 besluttede at lukke sin vindmøllefabrik i Varde, hvilket ville betyde, at 120 højt specialiserede arbejdspladser ville gå tabt. Men den kinesiske vindmølleproducent, Titan Wind Energy, købte fabrikken, gjorde Varde til sit europæiske hovedkvarter og bevarede derved hovedparten 


\section{Yang fiang}

af de 120 arbejdspladser. Et andet lignende eksempel er samarbejdsaftalen mellem TDC (Danmarks største teleselskab) og Huawei i 2013, som medførte 200 nye jobs i Danmark. Men her er de økonomiske fordele tilsyneladende ikke nok til at sikre Huawei sin position i Danmark, hvilket vil blive diskuteret senere i denne artikel.

Imidlertid har en række episoder de sidste to år, som vil blive diskuteret nedenfor - og USA's kampagne mod Kina - ført Danmarks politik i forhold til Kina og kinesiske investeringer i en mere ambivalent og forsigtig retning. ${ }^{1}$

Bekymringerne er for det første politisk-ideologisk begrundede: Kinesiske investeringer kan indgå som en del af Beijings udenrigspolitiske værktøjer og dermed true danske kerneværdier om demokrati og menneskerettigheder; for det andet strategiske: Kinesiske investeringer i kritisk infrastruktur kan bruges som sikkerhedsforposter eller bagveje til kritisk information og kontrolsystemer, og dermed true Danmarks nationale sikkerhed samt USA's sikkerhedsinteresser i regionen. I medierne er de førnævnte episoder blevet kaldt "skandaler", hvor Kina forsøgte at lægge pres på Danmark i sager om Tibet, Falun Gong og ulovlig brug af kinesisk arbejdskraft. Og selvom anklagerne stadig enten er under efterforskning, tilbagevist af Kina eller pga. manglende bevisførelse, har de givet betydelige ridser i billedet af kinesisk tilstedeværelse i Danmark. Denne type frygt er blevet forværret af diskussionen om Kinas såkaldte "sharp power" - hvilket henviser til Kinas brug af oversøiske kinesiske og udenlandske institutioner til for det første at forsvare sit eget politiske system og for det andet at forfølge sine egne politisk-strategiske interesser - i bl.a. Australien og USA - en diskussion som også har fået omfattende mediedækning og er blevet omtalt af politikere, der er modstandere af Kina, som noget, "europæerne også kan

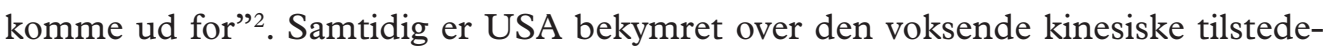
værelse i Europa og Arktis og har lagt direkte pres på Danmark for at holde kinesiske investeringer ude af Grønlandsk infrastruktur (Hinshaw \& Page, 2019). Mere om dette senere. Den danske politiker, Søren Espersen, der på daværende tidspunkt var formand for Udenrigspolitisk Nævn, var meget tydelig i sine udtalelser om den kinesiske trussel i Danmark (Dit Overblik, 2018). Espersen var udenrigspolitisk ordfører for højrefløjspartiet, Dansk Folkeparti, som opnåede stor popularitet ved valget $\mathrm{i}$ 2015 pga. sin hårde indvandrerpolitik og nationalistiske dagsordner, og som fik en nøglerolle som det parlamentariske grundlag for partiet Venstres mindretalsregering.

Det er under disse ugunstige omstændigheder, at de kinesiske investeringer er blevet underlagt en højere grad af kontrol i de seneste to år. De næste to dele af artiklen vil diskutere hhv. kinesiske investeringer i Grønland og Huawei i Danmark, to sager med hver sine dynamikker. ${ }^{3}$

\footnotetext{
${ }^{1}$ For nærmere detaljer om disse hændelser, se Radio 24/7 2019.

2 Diskussionerne om "sharp power" i USA og Canada findes i: The Hoover Institution, 2018; Cole, 2018. Danske mediers rapporter om Kinas "sharp power" eller indblanding i indenrigspolitik findes i: Dombernowsky, 2018.

${ }^{3}$ Dele af de to sags-studier baserer sig på tre politiske rapporter: Jiang, Tonami \& Fejerskov, 2016; Jiang 2017; Jiang, 2018.
} 


\section{Grønland}

Grønland har politisk selvstændighed fra Danmark undtagen inden for udenrigs- og forsvarspolitik, hvilket er slået fast i Lov om Grønlands Selvstyre fra 2009. Men det er hævet over enhver tvivl, at Grønland gennem økonomisk bæredygtighed ønsker at opnå fuld uafhængighed af Danmark. Grønland forsøger at overgå fra en økonomi baseret på fiskeri og et bloktilskud fra Danmark til en økonomi baseret på turisme og minedrift for på den måde at opnå økonomisk uafhængighed fra Danmark. Der er dermed et godt match mellem Grønlands målsætning og den kinesiske regering og kinesiske selskabers ønsker inden for minedrift og infrastruktur omkring de arktiske sejlruter.

Dette har i Danmark, især i Forsvarsministeriet og efterretningstjenesterne ført til spørgsmål om Beijings støtte til Grønlands selvstændighed og om mulige sikkerheds-implikationer for USA's militærbase i Thule (Matzen, 2017; Jensen, 2018; Breum, 2018). Udgivelsen af Kinas første hvidbog om landets arktiske politik (State Council of the People's Republic of China, 2018) i januar 2018, som definerede Kina som en "nær-arktisk stat", med det prominente mål at etablere en arktisk Silkevej, har ikke dæmpet nervøsiteten, tværtimod.

Udenlandsk indblanding i uran-udvinding og eksport fra Grønland er et konfliktfyldt emne, fordi det potentielt har betydning for dansk suverænitet og udenrigspolitik - og her er Danmark bundet af Ikke-spredningstraktaten. Men fordi sjældne jordarter og andre mineraler opfattes som en afgørende kilde til økonomisk vækst, har Grønland gradvist erhvervet sig rettighederne til efterforskning og eksport med en lov fra 2014, der tillader udenlandsk arbejdskraft på store projekter og en samarbejdsaftale med Danmark fra januar 2016, om hvordan der skal samarbejdes om udenrigs-, forsvars- og sikkerhedspolitiske emner, der er relateret til udvinding og eksport af uran fra Grønland (Boersma \& Foley, 2014; World Nuclear News, 2016).

I 2014 og 2015 fik kinesiske selskaber, takket være gensidig forståelse mellem den grønlandske regering og udenlandske investorer i Grønland, andele eller licenser i fire mineprojekter - Kvanefjeld mine for sjældne jordarter, Isua jernmine, Citronen-projekt til udvinding af uædle metaller og Wegener Halvø kobbermine. De fire projekter er alle i de indledende faser, dvs. enten under udforskning, i processen med at foretage miljømæssige, sociale og økonomiske vurderinger eller afventende de sidste tilladelser fra regeringen. Det største projekt, som også er tættest på at kunne realiseres, er Kvanefjeld mine for sjældne jordarter, ejet af det australske Greenland Minerals and Energy (GME), hvoraf en andel på 12,5\% er ejet af det kinesiske selskab, Shenghe (China Business, 2017). Mens mange grønlændere ser frem til mulighederne og den nye dynamik, som projektet vil tilføre øen, er man i lokalsamfundene samtidigt bekymrede for de miljømæssige konsekvenser. GME har brugt årevis og millioner af dollars på at håndtere bekymringerne for miljøet, samtidig med at miløøorganisationer igen og igen sætter spørgsmålstegn ved konklusionen om "nul-risiko", som miljøpåvirkningsvurderingen er kommet frem til (Lucht, 2018). 
Sammenlignet med mineprojekterne har kinesisk engagement i infrastrukturprojekter, inklusive udvidelsen af Grønnedal Flådebase og tre lufthavne, været langt mere omstridte og blev hovedårsagen til lovgivningen om udenlandske investeringer i kritisk infrastruktur. Ikke mindst fordi USA har en strategisk vigtig flyvebase i Thule, som bl.a. indeholder en radarstation, der er en del af USA's tidlige varslingssystem for ballistiske missiler. Grønlandstraktaten, som er en forsvarstraktat mellem Danmark og USA fra 1951, giver USA omfattende beføjelser inden for forsvarsområdet.

General Nice, et privat kinesisk firma, der i 2015 opnåede rettigheder inden for minedrift i Isua Jernåre for London Mining, var af uklare årsager interesseret i at købe Grønnedal Flådebase. Grønnedal - en forladt flådebase fra 2. Verdenskrig - var efterhånden blevet en økonomisk byrde for den danske regering, som besluttede at sætte basen til salg. Men da General Nice udtrykte interesse for basen, trak Danmark salget tilbage og annoncerede, at basen ville blive genåbnet som en strategisk og logistisk placeret base til træning af mandskab og opbevaring af brændstof. Anonyme kilder tæt på beslutningsprocesserne har forklaret, at Danmark "har et langt, tæt partnerskab med USA og en forsvarsaftale i Grønland fra april 1951 at tage højde for" og at "Danmark ikke kan tillade, at to supermagter leger kispus i Grønland" (Matzen, 2017).

Det forlyder at Lars Løkke Rasmussen personligt greb ind for at stoppe salget, og endda at det skete efter direkte ordre fra Washington (Breum, 2016; Matzen \& Daly, 2018). Ikke desto mindre lader det til, at Danmark på daværende tidspunkt hverken ønskede at fornærme USA eller Kina, for officielt blev det ikke udtrykt, at der var sammenhæng mellem Kinas interesse i Grønnedal og tilbagetrækningen af salget, og Danmark valgte slet ikke at sælge basen.

Men da det kinesiske, statsejede selskab, China Communications Construction Company (CCCC) blev shortlistet som en mulig kontraktor til at bygge og udvide tre lufthavne i Nuuk, Ilulissat og Qaqurtoq i marts 2018, skjulte de danske embedsmænd ikke længere hverken deres utryghed over kinesisk strategisk tilstedeværelse og politisk indflydelse i Grønland eller den danske uvilje mod at støde USA. En højtrangerende dansk embedsmand sagde i et interview med Reuters: "Vi er stærkt bekymrede, Kina har intet at gøre i Grønland... Danmark har et stort ansvar at leve op til i forhold til USA, som vores nærmeste allierede" (Matzen \& Daly, 2018). Den daværende amerikanske forsvarsminister, James Mattis, mødte den daværende danske forsvarsminister, Claus Hjort Frederiksen, i Washington, DC i maj 2018 og advarede ham om sikkerhedsrisikoen ved Kinas investeringer i Grønland. Han trak paralleller til Kinas militærkonstruktioner i det Sydkinesiske hav (Danmarks Radio, 2018a). Danske medier og USA understregede samtidig risikoen for, at Grønland ville falde i Kinas "gældsfælde”. Grønland afviste disse betragtninger og affærdigede dem som udtryk for en gammeldags, kolonial tankegang og dobbeltmoral fra dansk side.

For at imødekomme amerikanernes bekymringer rejste den danske statsminister i september 2018 til Grønland for at indgå en aftale med den grønlandske 
regering, ifølge hvilken Danmark skulle delfinansiere og blive medejere af de nye lufthavne (Danmarks Radio, 2018b; Danmarks Radio, 2019). Få dage senere kom det amerikanske forsvarsministerium med en hensigtserklæring om at "arbejde intenst for potentielt strategiske investeringer [i Grønland] inklusive investeringer, der kunne tjene militære såvel som civile formål” (US Embassy Denmark, 2018). Selvom Danmark ikke bad Grønland om at slette CCCC, hvis tilstedeværelse på prækvalificeringslisten ikke faldt i god jord hos amerikanerne (Lucht, 2018), opgav CCCC i juni 2019 at byde på opgaven om at bygge lufthavne i Nuuk og Ilulissat (Reuters, 2019).

Et afgørende stridspunkt mellem Danmark og Grønland drejede sig om, hvorvidt lufthavnsprojekterne hører under forsvars- og udenrigspolitik, som Danmark råder over, eller under økonomisk og civile områder, som hører under Grønlands selvstyre. Dette kom til at påvirke Huaweis operationer i Danmark og er den direkte årsag til Danmarks nylige lov om screening af udenlandske investeringer, hvilket vil blive diskuteret nærmere.

\section{Huawei i Danmark}

Danmarks største teleselskab, TDC, underskrev i 2013 en kontrakt med Huawei om at opgradere og vedligeholde landets mobilnetværk i en 6-årig periode, en aftale til en værdi af 700 mio. \$. Da rygter om aftalen kom i omløb i 2013, opstod der ophedede debatter $\mathrm{i}$ offentligheden om sikkerhedsrisikoen ved at give et kinesisk selskab, der i 2012 blev anklaget af Den Amerikanske Kongres for spionage og brug af bagdøre til sikkerhedssystemerne, adgang til store dele af det danske telenetværk. Som et kompromis besluttede regeringen, at Center for Cybersikkerhed (CFCS, en institution under Forsvarets Efterretningstjeneste) skulle overvåge Huaweis arbejde på TDC's netværk; kun personer med sikkerhedsgodkendelse ville få tilladelse til at arbejde i Netværk Operations Centeret (NOC), der kontrollerer TDC's netværk, og at al hardware fra Huawei ville blive underlagt en screening i "The Cell” i UK, før det ville kunne blive installeret i Danmark. Denne ordning blev ramt af en skandale i 2015, da Danmarks Radio (DR) fandt en række tilfælde, hvor Huaweis ansatte arbejdede i NOC uden sikkerhedsgodkendelse. Men da de formelle institutionelle aftaler først var indgået som sikkerhedsgaranti, vandt Huawei uden vanskeligheder kontrakten om at opgradere TDC's netværk til 4G i 2016. De tests som TDC og Huawei lavede af 5G-systemet fra 2017, var en stor succes, og Huawei var fortrøstningsfulde i forhold til at vinde kontrakten om at udbygge Danmarks 5G-netværk.

Huawei kom i modvind i Danmark i 2018 og fik det afgørende slag i 2019, da TDC valgte svenske Ericsson fremfor Huawei til at bygge det nationale 5Gnetværk. Danmark tog til en vis grad højde for andre nordiske og europæiske landes holdninger til Huawei, heriblandt bekymringerne i Tyskland og debatter i Norge. Disse er i imidlertid ikke afgørende for TDC's beslutning af to årsager. For det første bevarede Danmark gode relationer med Kina, da norsk-kinesiske relationer befandt sig på et lavpunkt mellem 2010 og 2016, og da svensk-kinesiske relationer 


\section{Yang Fiang}

forringedes i begyndelsen af 2018. For det andet, selvom sikkerhedsbekymringer i Tyskland i forhold til at inkludere Huawei og sælge højteknologiske virksomheder til Kina blev bemærket i Danmark, blev reglerne vedrørende dets 5G-netværk ikke færdigforhandlet i Berlin før i oktober 2019, hvor det blev besluttet, at ingen aktør eller virksomhed skulle bandlyses præventivt. I stedet var det det amerikanske pres, der havde den mest afgørende effekt. Igennem 2018 optrappede USA handelskrigen mod Kina og indledte også en kampagne mod de kinesiske teleselskaber ZTE og Huawei. Som en del af "Nine Eyes" tele-efterretningsalliance følte Danmark et pres fra USA om at vælge side og bemærkede desuden, at en række lande allerede havde udelukket Huawei fra deres netværksinfrastruktur. I begyndelsen af 2019 udtrykte Danmarks daværende forsvarsminister, Hjort Frederiksen, bekymring over Huawei, og medierne gengav en dansk forskers mening om, at Danmark må vælge mellem spionage fra Kina eller fra USA (Christiani, 2019). Generelt udtrykkes der i de danske medier og blandt politiske beslutningstagere den holdning, at 5G-teknologi vil gennemtrænge både infrastruktur og dagligliv, og at risikoen ved at have Huawei som leverandør derfor er meget svær at vurdere. I februar 2019, midt under udbudsprocessen, blev to skandaler afsløret. De omhandlede Huaweis ulovlige brug af udenlandsk arbejdskraft og fortrolige møder mellem TDC og Huawei-ansatte uden sikkerhedsgodkendelse. Afsløringerne førte til udvisningen af to Huawei-ansatte (Kjeldtoft \& Markussen, 2019), og den 18. marts 2019 meddelte TDC, at man af kommercielle årsager ville vælge svenske Ericsson som leverandør af 5G i Danmark i slutningen af 2020. Hverken regeringsindgreb eller sikkerhedsgrunde var nævnt i meddelelsen (TDC Group, 2019).

\section{Afsluttende diskussion}

Denne artikel viser, at dansk politik omkring kinesiske investeringer er blevet ændret i løbet af 2018 - og dette skyldes hovedsageligt to faktorer: for det første fik USA's pres Danmark til at føle sig forpligtet til at holde Kina ude af grønlandsk infrastruktur og dansk telenetværk pga. sikkerhedsalliancen. Samtidig blev forsvarspolitikken og efterretningstjenesterne overbeviste om, at Kina ville udgøre en sikkerhedstrussel. Forholdsregler, som blev truffet af vestlige lande i APEC og EU for at øge kontrolmekanismerne over for udenlandske investeringer - med Kina som det implicitte mål - blev også truffet i København. For det andet har en række skandaler og episoder, der involverede Kina, fået omfattende dansk medieomtale gennem de sidste to år, hvilket har skæmmet Kinas omdømme i Danmark og fået nogle få danske, nationalistiske politikere til at rejse tvivl om Kinas hensigter og skabe frygt for Kina som en trussel mod det danske demokrati. Den oprindelige danske balance mellem økonomisk pragmatisme og demokratisk ideologi ser ud til at forskubbe sig mod sidstnævnte både i den politiske og i den offentlige diskurs, selvom de danske virksomheder forbliver positive i forhold til Kina. 
Som en afspejling af drejningen i den hjemlige politiske holdning samt accepten af en fleksibel, ikke-bindende EU-tilgang til indenrigspolitik støtter Danmark nu EU-kommissionens forslag om en rammeaftale om screening af direkte udenlandske investeringer, vedtaget i april 2019. Derudover nedsatte den daværende justitsminister, Søren Pape, i februar 2019, en tværministeriel arbejdskomité, der skulle lave et udkast til en lov om national screening af udenlandske investeringer, af hensyn til den nationale sikkerhed og den offentlige orden. Forslaget går på, at screeningen skal inkludere kritisk infrastruktur inden for energi, IT og telekommunikation, transport, fødevarer og sundhed såvel som investeringer i projekter, der involverer brug af avancerede teknologier som AI, robotteknologi eller nanoteknologi, og screeningen vil særligt være rettet mod virksomheder med tætte bånd til udenlandske regeringer (Hemmer, 2019). Blandt danske virksomheder er den herskende opfattelse af den kommende lovgivning, at problemet ikke er de kinesiske investeringer. Det er snarere manglen på kinesisk interesse $\mathrm{i}$ at investere, der er det. Mens de venter på detaljerne i loven, som endnu er på tegnebrættet, er danske virksomheder bekymrede for, at loven er elastisk, dvs., at den dækker et vidt spænd af sektorer og samtidig styrker statens politiske kontrol over virksomhederne i det hele taget (Jenvall, 2018). Med den nye centrum-venstre støttede socialdemokratiske regering ved magten efter valget d. 5. juni, er det ikke forventeligt at dansk udenrigspolitik tager nogen drastisk drejning i forhold til den forrige regerings førte politik, derimod vil en vis balancegang mellem pragmatiske erhvervsinteresser og voksende politiske og sikkerhedsmæssige bekymringer utvivlsomt fortsætte.

\section{Om artiklen}

Jeg er taknemmelig for den fine oversættelse af artiklen fra engelsk til dansk, udført af min danske lærer Catrine Werchmeister. Jeg skylder tak til Emma Katarina Andersen for at oversætte revisionen af artiklen. Jeg er også meget taknemmelig for nyttige kommentarer og inspiration fra redaktører og anonyme anmeldere under udarbejdelsen af artiklen. Bjørnar Sverdrup-Thygeson, Henrik Stålhane Hiim og Ulf Sverdrup skal have særlig tak for at invitere mig til at bidrage til projektet.

\section{Om forfatteren}

Yang Jiang er seniorforsker ved Dansk Institut for Internationale Studier. Hun forsker i Kinas politiske økonomi, herunder indenrigspolitiske dimensioner af økonomiske reformer, økonomisk diplomati, og udadgående investeringer.

\section{Referencer}

Baker \& McKenzie. (2016). Reaching New Heights: An update on Chinese investment into Europe. Hentet fra https:/www.bakermckenzie.com/-/media/files/insight/publications/2016/03/reaching-new-heights/ar_ emea_reachingnewheights_mar16.pdf?la=en 


\section{Yang Fiang}

Boersma, T. \& Foley, K. (2014). The Greenland gold rush: Promise and pitfalls of Greenland's energy and mineral resources. Washington, DC: The Brookings Institution.

Breinstrup, T. (2019, 1. marts). Indgrebslov mod udenlandske investeringer skal være klar inden nytår. Berlingske. Hentet fra https:/www.berlingske.dk/virksomheder/indgrebslov-mod-udenlandske-investeringer-skalvaere-klar-inden

Breum, M. (2016, 23. december). Did Denmark's prime minister stop a Chinese firm from buying an abandoned military base in Greenland? Arctic Today.

Breum, M. (2018, 30. juni). How a dispute over China and Greenland's airports worked its way toward a solution. Arctic Today.

China Business. (2017，24. juni). 盛和资源补“短板”: 欲购美国最大稀土矿(Shenghe Resources makes up for limitations: Wanting to buy US's biggest rare earth mine). Hentet fra http://www.cb.com.cn/ gongyeyucaikuang/2017_0624/1188458.html

Christiani, S. G. (2019, 18. februar). Forsker om Huawei-frygt: Danmark må vælge mellem spionage fra Kina eller USA. Danmarks Radio. Hentet fra https:/www.dr.dk/nyheder/udland/forsker-om-huawei-frygtdanmark-maa-vaelge-mellem-spionage-fra-kina-eller-usa

Cole, J. M. (2018). The hard edge of sharp power: Understanding China's influence operations abroad. The Macdonald- Laurier Institute. Hentet fra https://macdonaldlaurier.ca/files/pdf/20181022_MLI_ China\%27s_Influence_(Cole)_PAPER_WebreadyF.pdf

Danish Ministry of Finance. (2013, 26. february). Vækstplan DK - stærke virksomheder, flere job (Growth Plan DK-stronger companies, more jobs). Hentet fra https://www.fm.dk/publikationer/2013/vaekstplandk-staerke-virksomheder-flere-job/

Danmarks Radio. (2018a, 25. maj). USA advarer Claus Hjort om kinesisk entreprenør på Grønland. Hentet fra https://www.dr.dk/nyheder/politik/usa-advarer-claus-hjort-om-kinesisk-entreprenor-pa-gronland

Danmarks Radio. (2018b, 10. september). Løkke vil bruge 700 millioner på lufthavne i Grønland: 'En historisk dag'. Hentet fra https://www.dr.dk/nyheder/politik/loekke-vil-bruge-700-millioner-paa-lufthavne-igroenland-en-historisk-dag

Danmarks Radio. (6. marts 2019). Ejeraftale om grønlandske lufthavne er underskrevet. Hentet fra https:// www.dr.dk/nyheder/politik/ejeraftale-om-gronlandske-lufthavne-er-underskrevet

Det Udenrigspolitiske Nævn. (2009). Det Udenrigspolitiske Nævn 2009-10, UPN Alm. del Bilag 24. Hentet fra https://www.ft.dk/samling/20091/almdel/upn/bilag/24/772818/index.htm

Dit Overblik. (2018, 13. november). Søren Espersen: Danmark skal sige fra overfor Kinas chikane.

Dombernowsky, L. (2018, 26. februar). Kinas indflydelse i New Zealand viser, hvad der venter os i Europa. Information.

Hanemann, T., Huotari, M. \& Kratz, A. (2019). Chinese FDI in Europe: 2018 trends and impact of new screening policies. Rhodium Group \& the Mercator Institute for China Studies. Hentet fra https://rhg. com/wp-content/uploads/2019/03/RHG-MERICS-COFDI-Update-2019.pdf

Hemmer, P. (2019, 27. marts). Government to introduce screening of foreign direct investments and regulatory intervention. Bech Brunn. Hentet fra https:/www.bechbruun.com/en/news/2019/regeringen-vil-indfrescreening-af-udenlandske-investeringer-og-indgrebslov

Hinshaw, D. \& Page, J. (2019, 10. februar). How the Pentagon countered China's designs on Greenland. The Washington Street fournal.

Hoover Institution. (2018). Chinese influence and American interests: Promoting constructive vigilance. Hentet fra https://www.hoover.org/sites/default/files/research/docs/chineseinfluence_americaninterests_ fullreport_web.pdf

Jensen,T. (2018, 27. marts). Greenland shortlists Chinese company for airport construction despite Denmark's concerns. Reuters.

Jenvall, L. (2018, 19. november). Erhvervslivet: Kinas investeringer i Danmark er ikke problemet - det er manglen på dem. Danmarks Radio. Hentet fra https://www.dr.dk/nyheder/politik/erhvervslivet-kinasinvesteringer-i-danmark-er-ikke-problemet-det-er-manglen-paa-dem

Jiang, Y., Tonami, A. \& Fejerskov, A. M. (2016). China's overseas investment in critical infrastructure: Nuclear power and telecommunications. DIIS Report. Hentet fra http://pure.diis.dk/ws/files/727852/DIIS_ RP_2016_8_WEB.pdf

Jiang, Y. (2017). Chinese investment in Denmark: An open economy and rare political questions. I European Think-tank Network on China (ETNC), Chinese Investments in Europe (s. 47-53). Hentet fra https://www. clingendael.org/sites/default/files/2017-12/ETNC_Report_2017.PDF 
Jiang, Y. (2018). China in Greenland: Companies, governments, and hidden intentions? DIIS Policy Brief. Hentet fra https://www.diis.dk/en/research/china-in-greenland

Kjeldtoft, S. S. \& Markussen, C. (2019, 18. marts). TDC dropper Huawei: Ericsson skal levere 5G til Danmark. Politiken.

The Law Reviews. (2018). Foreign investment regulation review: Denmark. Hentet fra https://helawreviews. co.uk/edition/the-foreign-investment-regulation-review-edition-6/1174865/denmark

Lucht, H. (2018). Chinese investments in Greenland raise US concerns: Strictly business? DIIS Policy Brief. Hentet fra https://www.diis.dk/publikationer/chinese-investments-in-greenland-raise-us-concerns

Matzen, E. (2017, 6. april). Denmark spurned Chinese offer for Greenland base over security - sources. Reuters.

Matzen, E. \& Daly, T. (2018, 22. marts). Greenland's courting of China for airport projects worries Denmark. Reuters. Hentet fra https://www.reuters.com/article/china-arctic-greenland/greenlands-courting-of-chinafor-airport-projects-worries-denmark-idUSL4N1QP346

Ministry of Foreign Affairs of Denmark. (2017). China-Denmark joint work programme (2017-2020). Hentet fra http://kina.um.dk/ /media/Kina/Documents/ChinaDenmark\%20Joint\%20Work\%20Program\%20 $20172020 \% 20$ English.PDF?la=en

Radio 24syv. (2019) Kina i Kulissen. Hentet fra https://www.24syv.dk/kina

Reuters. (2019, 4. juni). China withdraws bid for Greenland airport projects: Sermitsiaq newspaper. Hentet fra https:/www.reuters.com/article/us-china-silkroad-greenland/china-withdraws-bid-for-greenland-airportprojects-sermitsiaq-newspaper-idUSKCN1T5191

Santander Trade Portal. (2019). Denmark: Foreign investment. Hentet fra https:/en.portal.santandertrade.com/ establish-overseas/denmark/foreign-investment?\&actualiser_id_banque=oui\&id_banque=54\&memoriser_ choix=memoriser

State Council of the People's Republic of China. (2018). China's Arctic policy' white paper. Hentet fra http:// english.gov.cn/archive/white_paper/2018/01/26/content_281476026660336.htm

TDC Group. (2019, 18. marts). TDC annoncerer plan for 5G-net. Hentet fra https://tdcgroup.com/da/newsand-press/nyheder-og-pressemeddelelser/2019/3/tdc-annoncerer-plan-for-5g-net13570503

U. S. Embassy Denmark. (2018, 17. september). Statement of intent on defense investments by the Department of Defense of the United States of America. Hentet fra https://www.facebook.com/denmark.usembassy/ photos/a.300218480736/10155753065265737/

World Nuclear News. (2016, 20. januar). WNN, Denmark and Greenland reach uranium export agreement. Hentet fra http://www.world-nuclear-news.org/UF-Denmark-and-Greenland-reach-uranium-exportagreement-2001165.html 20 January 2016

\section{Abstract in English \\ Denmark's Policy on Chinese Investments: \\ Pragmatism Balancing with Increasing Threat Perspectives}

During the past two years (2018-2019), Denmark's policy towards China has become more ambivalent. In particular, Denmark has become more cautious about inward Chinese investments. This article examines the factors that have affected Denmark's changing policy on Chinese investment, with two major case studies: Chinese investments in Greenland, and Huawei in Denmark. In a nutshell, it points out three decisive factors: first, the country's long-term ideology as a small, open economy, similar to other Nordic countries and as a member of the EU, with a pragmatic need for foreign markets; second, a strong national belief in democracy and the state's defense alliance with the United States, including its dedicated NATO membership; and third, the rise of xenophobic and nationalist political parties, challenging the earlier more balanced and pragmatic approach characteristic of larger parties as well as advocating a more anti-Chinese stance.

Keywords: Danish policy • Chinese investments • Greenland · Huawei 